\title{
IMPACT OF FEEDING NATURAL MICROBIAL RESOURCES ON LACTATING GOATS PERFORMANCE
}

\author{
Ebtehag, I.M. Abou-Elenin'; Etab R. Abd El-Galil' ; K.E.I. Etman ${ }^{1}$ and H.M. El- \\ Shabrawy ${ }^{1}$ \\ ${ }^{1}$ Department of Animal Nutrition, Animal Production Research Institute (APRI), Nadi El-Said St., \\ Dokki, Giza, Egypt.. Corresponding author: E-mail: eabouelenin@hotmail.com
}

${ }^{2}$ Department of Animal Production, Faculty of Agric. Ain Shams University, Egypt.

(Received 14/1/2015, accepted 15/3/2015)

\section{SUMMARY}

\begin{abstract}
$\mathrm{T}$ Whis study was conducted to study the effect of bacteria isolated, commercial enzymes and yeast culture as feed additives in rations of lactating Zaraibi Goats on nutrients digestibility, nutritive values, milk yield, milk composition, blood metabolites and economical return. Twenty four lactating Zaraibi Goats averaged $42.20 \pm 1.28 \mathrm{~kg}$ live body weight $(\mathrm{LBW})$ at the $3^{\text {rd }}$ and $4^{\text {th }}$ parities were assigned after parturition to four similar groups (6animals each). Animals were fed concentrate feed mixture and berseem at the rate of 60: $40 \%$ on DM basis, respectively (as a basal ration). The first group (G1) fed a basal ration without feed additives, the second group (G2) fed the basal ration with $10 \mathrm{~g} / \mathrm{doe} / \mathrm{day}$ of bacteria isolated, the third group (G3) fed a basal ration plus $10 \mathrm{~g}$ /doe/day of fibrozyme and the fourth group (G4) fed a basal ration with $10 \mathrm{~g} /$ doe/day of yeast culture (Saccharomyces Cerevisiae $1 \times 10^{9} \mathrm{CFU} / \mathrm{g}$ ) during 15 weeks of lactation period. Results indicated that rations of G2, G3 and G4 significantly $(\mathrm{P}<0.05)$ increased $\mathrm{DM}, \mathrm{OM}$ and $\mathrm{CF}$ digestibility in comparison with ration of G1. The second group (G2) was significantly $(\mathrm{P}<0.05)$ increased EE digestibility as compared to control and other additives rations. Group (G4) was significantly $(\mathrm{P}<0.05)$ higher in $\mathrm{CP}$ digestibility and $\mathrm{DCP} \%$ than other groups $(\mathrm{G} 1, \mathrm{G} 2$ and $\mathrm{G} 3)$. Animals fed rations supplemented with isolated bacteria or yeast culture had significantly $(\mathrm{P}<0.05)$ higher in TDN \% than those in others. Milk yield and fat corrected milk (4\% FCM) increased by (20.46\% and $21.19 \%$ ) for G3, (18.06\% and $17.34 \%$ ) for G4 and (14.28\% and $16.46 \%)$ for G2, respectively, compared to the control group. Milk content of fat, Protein, SNF and TS were significantly $(\mathrm{P}<0.05)$ higher in Goats fed rations G2 and G3 comparing with those in G1 and G4. Lactose was significantly $(\mathrm{P}<0.05)$ higher for G3. Feed efficiency values as $\mathrm{kg} 4 \%$ FCM per one $\mathrm{kg}$ DM, TDN or DCP were higher with G2, G3 and G4 rations than that of G1 ration. Blood parameters were in the normal physiological ranges with no adverse effect on dairy Goats health. Animals of $\mathrm{G} 4$ had a significantly $(\mathrm{P}<0.05)$ higher in concentration of plasma protein fraction (total protein, Albumin and globulin) compared with the others groups .The fourth group (G4) had significantly $(\mathrm{P}<0.05)$ higher for AST (IU/L) than G2. While, ALT value (IU/L) for G3 was significantly $(\mathrm{P}<0.05)$ higher than that in control ration $(\mathrm{G} 1)$. Economic efficiency value was the highest with G2 followed by G4 while, G3 had the lowest value as compared to the control ration G1. In general, results of the current study indicated that using bacteria isolated, fibrozyme and yeast culture as feed additives in lactating Goats rations plays important role in improving nutrients digestibility, feeding values, milk yield prolonged the persistency period and maintained body weight change. Economically, it is clear that bacteria isolated supplementation is superior to the other treatment groups and the cheapest price.
\end{abstract}

Keywords: enzymes extract, fibrolytic enzyme, yeast, digestibility, economic, doe.

\section{INTRODUCTION}

Animal protein for the Egyptian citizen is one of the most important goals in the sustainable agricultural development strategy until 2030. This objective comes through up grading productivity of animal wealth to increase human annual consumption of milk, this require increasing milk productivity of goats, cattle and buffaloes. A goal of ruminant microbiologists and nutritionists is to manipulate the ruminant microbial ecosystem to improve the efficiency of converting feed to products consumable by humans. 
Feed additives are important materials that can improve animal performance and feed efficiency. Yeast cultures has been used as a dietary supplement for dairy cattle and buffaloes to increase dry matter intake, milk production and milk composition (Adams,1995, Dann et al. 2000, Allam et al., 2001 and ElAshry et al., 2001) by stimulating growth of rumen bacteria, particularly cellulolytic species and improve fiber digestibility (Harrison et al. 1988). Yeast culture in ruminants diet has been shown to alter molar proportion of ruminal volatile fatty acid, increase acetate and decrease propionate and reduced ruminal $\mathrm{NH}_{3}$ concentration (Harrison et al., 1988, Newbold et al., 1990 and Dawson, 1993).

The use of enzymes as additives in ruminant diets has received considerable research interest and recently following positive responses observed in feeding trials. Four factors can be considered to determine if a feed additive should be used: anticipated response, economic return, available research and field responses (Hutjens, 1991). Dann et al. (2000) reported significant increases in dry matter intake when yeast culture was fed to transition cows resulting in higher milk yields and less weight loss postpartum. Fibrolytic enzymes (cellulase and xylanase activity) that in separate research investigations have been shown to reduce stress, enhance immune response, ruminal degradation of fiber, feed intake, average daily gain, and improve feed efficiency.

Therefore, this study was conducted to compare the effect of natural feed additives as(bacteria isolated secretion xylanase and cellulase activity), a commercial fibrozyme and, yeast culture (Saccharomyces Cerevisiae) in lactating Zaraibi Goat rations on nutrients digestibility, nutritive value, milk yield, milk composition and some blood metabolites of lactating Goats as well as economical return of the tested rations.

\section{MATERIAL AND METHODS}

The present study was carried out at El-Serw Research Station, belonging to Animal Production Research Institute, Agricultural Research Center. The objective of this work was conducted to study the effect of three natural forms supplementation, bacteria isolated (secretion cellulase and xylanase enzymes), fibrozyme and Yeast (Saccharomyces Cerevisiae $1 \times 10^{9} \mathrm{CFU} / \mathrm{g}$ ) in Lactating Zaraibi Goat rations on nutrients digestibility, nutritive value, milk yield, milk composition and some blood metabolites as well as economical return of the tested rations for lactation Goats from 1 to 15 weeks in milking period.

Twenty four lactating Zaraibi Goats averaged $42.20 \pm 1.28 \mathrm{~kg} \mathrm{LBW}$ at $3^{\text {rd }}$ and $4^{\text {th }}$ parities after parturition were divided to four similar groups according to parity, their body weight and average milk yield (six animals in each). The animals in all groups were fed concentrate feed mixture and berseem at rate of 60: $40 \%$ on dry matter (DM) basis, respectively (as a basal ration) for 15 weeks (feeding period).

The animals were randomly assigned to receive one of the four rations as following:

G1: control ration (concentrate feed mixture and berseem)

G2: control ration supplemented with $10 \mathrm{~g} /$ doe/day of bacteria isolated (secretion cellulase and xylanase enzymes)

G3: control ration supplemented with $10 \mathrm{~g} /$ doe/day of commercial fibrozyme

G4: control ration supplemented with $10 \mathrm{~g}$ /doe/day of yeast culture (Saccharomyces Cerevisiae).

The concentrate feed mixture consists of $34 \%$ yellow corn, $32.3 \%$ wheat bran, $20 \%$ undecorticated cotton seed meal, $10 \%$ soybean meal, $2 \%$ limestone, $1.0 \%$ sodium chloride, $0.5 \%$ minerals and vitamins mixture and $0.2 \%$ dicalcium phosphate. The concentrate feed mixture was offered two times daily just before milking at 6 a.m. and at 3 p.m. The amount of berseem was divided into two equal parts and offered at 9 a.m. and 6 p.m. Fresh water was offered twice daily before milking. The chemical composition of the ingredients and basal ration without additives are illustrated in Table (1).

Goats were hand milked twice daily at 7 a.m. and 4 p.m. Milk yields (morning and evening) were individual daily recorded. Actual milk yield was corrected to $4 \%$ FCM according to the formula of Gaines (1923). Representative milk samples of collected evening and morning milking were taken and refrigerated at $-4^{\circ} \mathrm{C}$ for milk analysis every two weeks. Milk samples were analyzed for total solid \% (Majennier, 1949), fat\% (Gerber method) by British Standard Instituting (1951), total protein and ash (Ling, 1963) and lactose were calculated by difference. 
Table (1): Chemical composition of feed ingredients and calculated chemical composition of basal ration ( $\%$ on DM basis).

\begin{tabular}{lccc}
\hline Item & \multicolumn{3}{c}{ Chemical analysis (\%) } \\
\cline { 2 - 4 } & Concentrate & berseem & Basal Ration \\
\hline Dry matter (DM) & 91.21 & 14.24 & 59.32 \\
Organic matter (OM) & 85.74 & 84.38 & 85.18 \\
Crude protein (CP) & 17.76 & 14.00 & 16.20 \\
Crude Fiber (CF) & 13.57 & 20.71 & 16.53 \\
Ether extract (EE) & 8.60 & 2.42 & 6.04 \\
Ash & 14.26 & 15.62 & 14.82 \\
NFE & 45.81 & 47.25 & 46.41 \\
Cell wall constituents (\%): & & & 35.17 \\
Neutral detergent fiber (NDF) & 31.24 & 40.72 & 18.53 \\
Acid detergent fiber (ADF) & 16.42 & 21.53 & 7.47 \\
Acid detergent lignin (ADL) & 9.36 & 4.81 & 16.64 \\
Hemicellulose & 14.83 & 19.19 & 11.06 \\
Cellulose & 7.06 & 16.72 & \\
\hline
\end{tabular}

Four digestibility trials were conducted using three Goats from each group. Dry matter and nutrient digestibility were determined using acid insoluble ash (AIA) technique of Van Keulen and Young (1977). Composite samples of feed and feces were analyzed according to A.O.A.C (2000). Neutral detergent fiber (NDF), acid detergent fiber (ADF) and acid detergent lignin (ADL) were determined according to Van Soest et al., (1991). Hemicellulose was calculated as (NDF-ADF) and cellulose as (ADF- ADL). Blood plasma samples were taken from jugular vein at the end of feeding trial from all animals and stored at $20^{\circ} \mathrm{c}$ till analysis. Plasma total protein, albumin, AST and ALT transaminase activities and creatinine were analyzed using commercial kits of Bio-Merieux, lab, France.

Data were statistically analyzed using general linear model program of SAS (1999). Digestibility and performance data were analyzed as one way analysis of variance according to the following model:

$$
\mathrm{Y}=\mathrm{u}+\mathrm{x}_{1}+\mathrm{e}_{\mathrm{ij}}
$$

where: $\mathrm{Y}=$ observation. $\mathrm{U}=$ mean, $\quad \mathrm{X}_{1}=$ the effect of treatment, $e_{\mathrm{ij}}=$ experimental error.

The significance of the differences among treatments was tested by Duncan (1955).

\section{RESULTS AND DISCUSSION}

\section{Nutrient digestibility and nutritive values:}

Data in Table (2) indicated that supplemented rations with bacteria isolated (G2), fibrozyme (G3) and yeast culture (G4) were significantly $(\mathrm{P}<0.05)$ increased $\mathrm{DM}$ and $\mathrm{CF}$ digestibilities as compared with control ration (G1). The highest CF digestibility was recorded with G2 (51.36\%) then G3 and G4 (48.84 and $46.20 \%$, respectively).

Bacteria isolated supplementation tended to significantly $(\mathrm{P}<0.05)$ decreased $\mathrm{CP}$ digestibility, while, digestibility of $\mathrm{OM}$ and EE significantly $(\mathrm{P}<0.05)$ increased compared to other additives.

Data presented in Table (2) showed that no significant differences among animals fed rations G1, G2, G3 and G4 in NFE digestibility, while, control ration recorded the lowest value of DM, OM, CF and EE digestibility except for CP and NFE digestibility. The differences were significant $(\mathrm{P}<0.05)$ between control ration and other supplementing rations. Furthermore, isolated bacteria (G2) supplementation had the highest values of DM, OM, CF and EE digestibility. It could be noticed that improving CF digestibility may be due to increase number of rumen cellulolytic bacteria (Gomez- Alcron et al., 1987) 
and increase in the population (Newbold et al.,1996) and/or activity of rumen cellulolytic bacteria (Dawson, 1993).

Adding yeast culture for ration (G4) tended to increase CP digestibility owing to yeast culture as a microbial protein and stimulation of rumen protelytic bacteria (Williams, 1991). Abou Elenin et al., (2011) who reported that using yeast culture as feed additives in lactating cows rations increased nutrients digestibility, feeding values, milk yield prolonged the persistency period and maintained body weight change. Yoon and Stern (1996) found that increasing DM, OM, CP and EE digestibility with animals fed supplemented rations compared with those fed control ration without supplementation may be due to the reflection of microbial supplements stimulated the growth and activity of certain ruminal microorganisms; in addition, Proteolytic bacteria counts were also stimulated by yeast culture, while, Chademana and Offer, (1990) found that yeast increased the initial rate of forage digestion in the rumen.

Table (2): Nutrients digestibility and nutritive values of lactating Zaraibi Goats fed experimental rations.

\begin{tabular}{|c|c|c|c|c|c|}
\hline \multirow[b]{2}{*}{ Item } & \multicolumn{4}{|c|}{ Experimental rations } & \multirow[b]{2}{*}{$\pm \mathrm{SE}$} \\
\hline & G1 & $\mathrm{G} 2$ & G3 & G4 & \\
\hline \multicolumn{6}{|l|}{ Digestibility coefficients, $\%$} \\
\hline $\mathrm{DM}$ & $57.49^{\mathrm{b}}$ & $65.21^{\mathrm{a}}$ & $64.28^{\mathrm{a}}$ & $64.21^{\mathrm{a}}$ & 1.49 \\
\hline $\mathrm{OM}$ & $56.33^{\mathrm{c}}$ & $67.49^{\mathrm{a}}$ & $61.83^{\mathrm{b}}$ & $66.98^{a}$ & 1.29 \\
\hline $\mathrm{CP}$ & $78.05^{\mathrm{b}}$ & $73.82^{\mathrm{c}}$ & $75.16^{\mathrm{cb}}$ & $83.11^{\mathrm{a}}$ & 0.98 \\
\hline $\mathrm{CF}$ & $24.07^{\mathrm{b}}$ & $51.36^{\mathrm{a}}$ & $48.84^{\mathrm{a}}$ & $46.20^{\mathrm{a}}$ & 2.79 \\
\hline $\mathrm{EE}$ & $74.31^{\mathrm{b}}$ & $81.50^{\mathrm{a}}$ & $76.29^{\mathrm{b}}$ & $75.37^{\mathrm{b}}$ & 1.59 \\
\hline NFE & 62.14 & 68.01 & 61.64 & 68.88 & 5.11 \\
\hline \multicolumn{6}{|l|}{ Cell wall constituents (\%): } \\
\hline $\mathrm{NDF}$ & 50.60 & 53.42 & 52.54 & 53.06 & 4.02 \\
\hline $\mathrm{ADF}$ & $49.32^{\mathrm{a}}$ & $64.64^{\mathrm{a}}$ & $56.40^{\mathrm{a}}$ & $27.36^{\mathrm{b}}$ & 4.65 \\
\hline ADL & $54.70^{\mathrm{a}}$ & $57.90^{\mathrm{a}}$ & $59.04^{\mathrm{a}}$ & $11.61^{b}$ & 5.48 \\
\hline Hemicellulose & $52.02^{\mathrm{b}}$ & $40.91^{\mathrm{b}}$ & $48.25^{\mathrm{b}}$ & $81.69^{\mathrm{a}}$ & 5.58 \\
\hline Cellulose & $45.69^{\mathrm{ab}}$ & $69.22^{\mathrm{a}}$ & $54.60^{\mathrm{ab}}$ & $38.02^{\mathrm{b}}$ & 7.29 \\
\hline \multicolumn{6}{|l|}{ Nutritive values (\%): } \\
\hline TDN\% & $55.55^{\mathrm{b}}$ & $63.11^{\mathrm{a}}$ & $59.25^{\mathrm{b}}$ & $63.33^{\mathrm{a}}$ & 0.87 \\
\hline $\mathrm{DCP} \%$ & $12.65^{\mathrm{b}}$ & $11.97^{\mathrm{c}}$ & $12.19^{\mathrm{bc}}$ & $13.47^{\mathrm{a}}$ & 0.15 \\
\hline $\mathrm{DE} \mathrm{kcal} / \mathrm{Kg} \mathrm{DMI}^{\mathrm{A}}$ & 2.45 & 2.78 & 2.61 & 2.79 & - \\
\hline
\end{tabular}

A: $D E($ Mcal $/ \mathrm{Kg} D M I)=0.04409 \times T D N \% . \quad(N R C, 1988) \quad S E=$ standard error

$a, b$ and $c$ : Means in the same rows with differ rent superscripts are significantly different at $(P<0.05)$.

Neutral detergent fiber $(N D F)$ Acid detergent fiber $(A D F)$ Acid detergent lignin (ADL)

$G 1=$ control,$\quad G 2=$ bacteria isolated,$\quad G 3=$ fibrozyme,$\quad G 4=$ yeast

No significant differences in NDF digestibility values among four treatments, while, ADF and ADL were the lowest digestibility values with Group 4, which reflects on Hemicellulose values. Bacteria isolated supplementation $(\mathrm{G} 2)$ was significant $(\mathrm{P}<0.05)$ higher with cellulose $(69.22 \%)$ than yeast culture supplementation group (38.02\%). Digestibility of ADF for (G2) which supplemented with bacteria isolated (cellulase and xylanase enzymes) and (G3) which supplemented with Fibrozyme increased with rate of $31 \%$ and $14 \%$; respectively than that in control ration. These results were reflection on $\mathrm{CF}$ digestibility. The results were harmony with Krause et al. (1998) who reported that ADF digestibility increased $(28 \%)$ by using cellulase and xylanase enzymes product when its added to a high-concentrate diet. However, Supplementing Enzyme by the end of pregnancy and the first $60 \mathrm{~d}$ of lactation of ewes and goats Enzyme reducing dietary ADF and NDF concentrations (McAllister et al., 2001). Furthermore, Hristov et al. (1998) indicated that addition of fibrolytic enzymes to ruminant diets increased total tract digestibility of DM and NDF. In addition, Beauchemin et al., (2003) reported that adding exogenous Fibrolytic enzymes to dairy cow and feedlot cattle diets can potentially improve cell wall digestion and the efficiency of feed utilization by ruminants.

The nutritive values as TDN \% in Table (2) noticed that control ration without additive had $(\mathrm{P}<0.05)$ the lowest value while, rations of $\mathrm{G} 2$ and $\mathrm{G} 4$ were recorded significantly $(\mathrm{P}<0.05)$ the highest value of 
TDN. Also, isolated bacteria (G2) and G4 supplementation recorded the higher value of DE (Mcal/ Kg DMI) than those fed the control ration (G1) or those supplemented with fibrozyme (G3). These result were confirmed with El-Ashry et al. (2001) who noticed that supplemented rations with yeast $(\mathrm{P}<0.05)$ increased feeding value of ration comparing with control. Abd El-Galil (2014) found that nutritive values as TDN for ration supplemented with either value fibrozyme or with mix- Fibrozyme + yeast were significantly $(\mathrm{P}<0.05)$ higher $(63.72 \%$ and $64.34 \%$, respectively) than that supplemented with yeast culture $(61.92 \%)$ then the lowest value was found with control ration without supplements $(59.31 \%)$.

The DCP values were significantly $(\mathrm{P}<0.05)$ increased with ration of $\mathrm{G} 4$ than those in the other rations. This result was reflected to increase values of $\mathrm{CP}$ digestibility. These results are agreement with report of Abd El-Galil (2014) who recorded that DCP had a higher significantly values for ration supplemented with fibrozyme or yeast or mixed of them than ration without supplement.These results means that biological additives which may be increasing the number of bacteria in the rumen, increasing the digestibility and nutritive values of the experimental diets.

Different schemes have been drawn up by different authors to draw together into a logical mode of action the various observations that have been made on microbial feed additives (Williams, 1989; Offer, 1990 and Wallace and Newbold, 1992). These reflect our most recent findings and attempts to form the observations into a sequence. The improved feed intake seems to be driven partly by an improved rate (but usually not extent) of fiber breakdown (Wallace and Newbold, 1992) and partly by an improved duodenal flow of absorbable amino-nitrogen (Williams et al., 1990). These two observations are suggested to arise from a more active microbial population: the most effect of microbial feed additives is that they increase the viable count of anaerobic bacteria recovered from ruminal fluid. Increases of 50 to $100 \%$ are common (Wallace and Newbold, 1993), but increases of more than 10-fold compared with controls have been observed. Cellulolytic bacterial numbers are increased (Wallace and Newbold, 1993) thus explaining in part the improvement in fiber breakdown and increased stability of the fermentation in animals receiving yeast and A. oryzae (Harrison et al., 1988 and Williams et al., 1991). Nitrogen balance and metabolism was found to be improved due to the inclusion of yeast culture in the diet of sheep. This may have been due to the increase in $\mathrm{N}$ digestibility as well as to a better utilization of the dietary $\mathrm{N}$. Proteolytic bacteria count was increased and the flow of non-microbial non-ammonia $\mathrm{N}$ tended to be higher for cows fed yeast culture (Yoon and Stern, 1996 and Putnam et al., 1997).

\section{Feed intake and body weight changes:}

Data in Table (3) showed that feed intake of concentrate feed mixture (CFM), berseem and roughage/concentrate ratios were almost similar among all the tested rations with or without supplements. Feed intake (kg/doe/day) as DM, TDN and DCP slightly increased with supplemented rations (G2, G3 and G4) compared with control ration (G1). These results are in agreement with the results of Allam et al. (2001), El-Ashry et al. (2001 and 2003) and Salem et al. (2001). They reported that there was a significant improvement in DM intake when yeast culture was given to lactating animals. Also, these results reflects on the changed in body weight.

Results of Dyaa El-Din et al. (2013) indicated that lactating dairy cows which fed (with or without) a supplement of exogenous fibrolytic enzymes had no significant changes in DMI at early lactation. Yeast culture in other studies improved milk yield in dairy cows, but others reported no effect with dairy cows' or dairy ewes and goats (Hadjipanayiotou et al., 1997). Feeding yeast culture increase the mean group in feed intake with significant differences among groups, however, were not tested statistically due to the group feeding system applied in the present study. Hadjipanayiotou et al. (1997) reported that no effect of yeast culture on DM intake. Several researchers recorded an increase in DMI of dairy cows when fibrolytic enzymes was applied to forage before mixing with other ingredients (Lewis et al., 1999) or applied to TMR or concentrate portion of the diet (Bowman et al., 2002; Ware and Zinn, 2005). However, the effects of fibrolytic enzymes on DMI appear to be vary among enzymes products and the method of applying of enzymes (Bowman et al., 2002)

Data presented in Table (3) showed that body weight changes were slightly decreased with animals fed fibrozyme $(\mathrm{G} 3 ;-3.2 \mathrm{~kg})$ followed by bacteria isolated $(\mathrm{G} 2 ;-4.0 \mathrm{~kg})$ and then yeast culture $(\mathrm{G} 4 ;-4.3 \mathrm{~kg})$ supplemented ration, although, animals fed G3 had equal with these fed G4 in feed intake as dry matter. While, animals fed control ration without supplement had a highest reduction in live body weight (G1; $5.5 \mathrm{~kg}$ ). These results reflecting the mobilization of body reserves, as indicated by the negative energy balance. These results were confirmed with results of Abou-Elenin et al. (2011) who found that using yeast culture as feed additives in lactating cows' rations maintained body weight change. 
Table (3): Average feed intake and body weight changes (kg) of lactating Zaraibi Goats fed experimental rations.

\begin{tabular}{|c|c|c|c|c|}
\hline \multirow{2}{*}{ Item } & \multicolumn{4}{|c|}{ Experimental rations } \\
\hline & G1 & G2 & G3 & G4 \\
\hline \multicolumn{5}{|l|}{ Feed intake (kg/doe/day) as fed: } \\
\hline Concentrate feed mixture (CFM) & 0.98 & 1.01 & 1.03 & 1.02 \\
\hline Berseem & 4.44 & 4.50 & 4.60 & 4.63 \\
\hline Total & 5.42 & 5.51 & 5.63 & 5.65 \\
\hline Feed additives & ---- & 0.01 & 0.01 & 0.01 \\
\hline \multicolumn{5}{|c|}{ Feed intake (kg/doe/day) on DM basis: } \\
\hline Concentrate feed mixture (CFM) & 0.89 & 0.92 & 0.94 & 0.93 \\
\hline Berseem & 0.63 & 0.64 & 0.66 & 0.66 \\
\hline Total DM intake & 1.52 & 1.56 & 1.59 & 1.59 \\
\hline Feed additives $(\mathrm{kg})$ & ---- & 0.01 & 0.01 & 0.01 \\
\hline TDN intake & 0.85 & 0.95 & 0.98 & 0.97 \\
\hline DCP intake & 0.20 & 0.19 & 0.20 & 0.21 \\
\hline Roughage/concentrate & 40:60 & $40: 60$ & $40: 60$ & $40: 60$ \\
\hline \multicolumn{5}{|l|}{ Body weight, kg: } \\
\hline Initial body weight & 42.2 & 42.0 & 42.8 & 41.8 \\
\hline Final body weight & 36.7 & 38.0 & 39.7 & 37.5 \\
\hline Duration, weeks & 15 & 15 & 15 & 15 \\
\hline Change in body weight & -5.5 & -4.0 & -3.2 & -4.3 \\
\hline
\end{tabular}

On average, recent data indicate that microbial additives may benefit ruminant nutrition (in terms of live weight gain and milk production) by a similar magnitude to ionophores ( 7 or $8 \%$ improvement; Wallace and Newbold, 1993), by increasing feed intake rather than feed efficiency (Williams and Newbold, 1990).

Recent work with different strains of yeast and respiration-deficient yeast mutants demonstrates that the ability of yeast to stimulate the viable count in the rumen depends on its respiratory activity (Newbold et al., 1993). It is proposed that yeast removes some of the $2 \times 10^{2}$ that occurs in ruminal fluid at various times during the daily feed cycle (Hillman et al., 1985) and, therefore, prevents toxicity to the ruminal anaerobes. Less attention had been focused on the precise mode of action of A. oryzae, but again, the activity is destroyed by autoclaving but not by irradiation (Newbold et al., 1992). Regardless of the efficacy or mode of action of microbial feed additives, they are already in widespread use. They may, in addition, offer new opportunities for manipulation.

The rumen bacteria change qualitatively and quantitatively were responded to the changes in chemical composition of diet of the animals (Maklad and Mohamed, 2001). The main effect of yeast culture is to stabilize the rumen environment. Concentrations of cellulolytic and anaerobic bacteria were higher in In vitro and In vivo systems. A reduction in rumen lactic acid concentrations were reported by (Williams, 1989). Hutjens (1991) refers to expected performance changes when animals fed on a feed additive which several examples were higher milk yield, increase in milk components (protein and/or fat), greater DM intake, simulate rumen microbial synthesis, increase digestibility, stabilize rumen environment and $\mathrm{pH}$ value.

Abd El-Galil (2014) reported that biological additives on basal diet for feedlot Baladi goats with fibrozyme and a combination of yeast culture and fibrozyme tended to enhance dry matter intake and ruminal digestion for kids which reflex on increasing in all, OM, CP and CF digestibility than that in the control ration. These reflected on growth and activity of cellulolytic bacteria. Feeding on basal ration with biological additives may increase growth types of microorganisms which improve efficiency of using diets. Mekasha et al. (2002) who observed that the high DM intake could a result of lower fiber content and high $\mathrm{CP}$ content in basal diet.

\section{Milk production and composition:}

Results presented in Table (4) showed that milk and $4 \%$ fat corrected milk yields (FCM; $\mathrm{kg} /$ doe.day) of the lactating Goats were significantly $(\mathrm{P}<0.05)$ increased with supplemented rations by $\mathrm{G} 3, \mathrm{G} 4$ and $\mathrm{G} 2$ than those fed control ration. The yield of milk and 4\% FCM of lactating Zaraibi Goats were increased by 
$20.53 \%$ and $21.43 \%$ for $\mathrm{G} 3,17.89 \%$ and $17.58 \%$ for $\mathrm{G} 4$ and $14.21 \%$ and $16.48 \%$ for G2 supplementation, respectively, compared with the control group. Similar result was detected with Gaafar et al., 2009 and Rahma et al., 2009 who reported that yeast culture supplementation, significantly $(\mathrm{P}<0.05)$ increase milk yield during early lactation compared to control group.

The increase in milk yield with fibrozyme (G3) and/ or bacteria isolated (G2) supplementation might be due to increase microbial protein or reducing methan production in the rumen (Newbold et al., 2005) and improve microbial efficiency by maintaining higher $\mathrm{pH}$, optimum ammonia nitrogen and essential volatile fatty acid (VFA's). Also, increasing milk yield with yeast culture (G4) supplementing ration than that in control ration might be attributed to the fact as a source of B vitamins which may occasionally be beneficial, increasing the microbial protein flow from rumen (Williams et al., 1990), reducing ammonia nitrogen concentration in the rumen by the inhibitory effect of growth promoters on proteolysis, amino acid determination and ruminal ureas activity (Khattab et al., 2003). These results confirmed with AbouElenin et al. (2011) who found that using yeast culture as feed additives in lactating cows' rations increased milk yield prolonged the persistency period and maintained body weight change. In addition to, Exogenous fibrolytic enzymes supplement to the diet of lactating dairy cows improved $(\mathrm{P}<0.003)$ milk yield, fat corrected milk $(\mathrm{P}<0.025)$ and feed efficiency $(\mathrm{P}<0.001)$ compared to untreated dairy cows Dyaa El-Din et al. (2013).

Table (4): Daily milk yield and composition of lactating Zaraibi Goats fed experimental rations.

\begin{tabular}{|c|c|c|c|c|c|}
\hline \multirow[t]{2}{*}{ Item } & \multicolumn{4}{|c|}{ Experimental rations } & \multirow[t]{2}{*}{$\pm \mathrm{SE}$} \\
\hline & G1 & G2 & G3 & G4 & \\
\hline Milk yield (kg/doe/day) & $1.90^{\mathrm{d}}$ & $2.17^{\mathrm{c}}$ & $2.29^{a}$ & $2.24^{\mathrm{b}}$ & 0.003 \\
\hline 4\% FCM yield (kg/doe/day) & $1.82^{\mathrm{c}}$ & $2.12^{\mathrm{b}}$ & $2.21^{\mathrm{a}}$ & $2.14^{\mathrm{b}}$ & 0.008 \\
\hline Improvement in milk yield & 100 & 114.21 & 120.53 & 117.89 & - \\
\hline Improvement in $4 \%$ FCM yield & 100 & 116.48 & 121.43 & 117.58 & - \\
\hline \multicolumn{6}{|l|}{ Composition of milk (\%): } \\
\hline Fat & $3.74^{\mathrm{bc}}$ & $3.86^{\mathrm{a}}$ & $3.78^{\mathrm{b}}$ & $3.70^{\mathrm{c}}$ & 0.024 \\
\hline Protein & $3.41^{\mathrm{b}}$ & $3.47^{\mathrm{a}}$ & $3.46^{\mathrm{a}}$ & $3.39^{\mathrm{b}}$ & 0.009 \\
\hline Lactose & $4.81^{\mathrm{b}}$ & $4.82^{\mathrm{b}}$ & $4.86^{\mathrm{a}}$ & $4.79^{\mathrm{b}}$ & 0.016 \\
\hline $\mathrm{SNF}^{\mathrm{A}}$ & $8.95^{\mathrm{b}}$ & $9.03^{\mathrm{a}}$ & $9.07^{\mathrm{a}}$ & $8.93^{b}$ & 0.022 \\
\hline $\mathrm{TS}^{\mathrm{B}}$ & $12.71^{\mathrm{b}}$ & $12.89^{\mathrm{a}}$ & $12.84^{\mathrm{a}}$ & $12.63^{\mathrm{b}}$ & 0.033 \\
\hline Ash & 0.75 & 0.75 & 0.75 & 0.75 & 0.003 \\
\hline
\end{tabular}

Data in Table (4) showed that milk content of fat, Protein, lactose, SNF and TS\% were significantly $(\mathrm{P}<0.05)$ decreased with Goats fed ration containing yeast culture (G4) and control ration $(\mathrm{G} 1)$ compared with those fed enzymes at G2 and G3. Also, animal fed ration supplemented with isolated bacteria (G2) appeared to be significantly $(\mathrm{P}<0.05)$ higher in milk fat percentage. While, goats fed ration supplemented with fibrozyme $(\mathrm{G} 3)$ had significantly $(\mathrm{P}<0.05)$ higher in milk protein and lactose percent than those in other experimental rations. There were no significant differences among groups in milk ash percent. These results were confirmed by Hutjens (1991) who refers to expected performance changes when animals fed on a feed additive which several examples were higher milk yield, increase in milk components (protein and/or fat), simulate rumen microbial synthesis, and improve health (less ketosis, reduce acidosis and increase immune response). The results of Dyaa El-Din et al., (2013) denoted that supplementation of exogenous fibrolytic enzymes (Fibrozyme) had no significant effect on milk fat, protein, lactose and solid not fat (SNF) percentage compared to the control group of dairy cows. While, the quantities of milk protein $(1.36 \mathrm{vs} .1 .30 \mathrm{~kg})$, lactose $(2.0 \mathrm{vs} .1 .92 \mathrm{~kg})$ and $\mathrm{SNF}(3.47 \mathrm{vs} .3 .31 \mathrm{~kg}) \mathrm{in}$ supplemented-dairy cows were improved significantly compared to the control group except quantity of milk fat $(\mathrm{P}<0.096)$. Furthermore, Gaafar et al. (2009) found that the contents of all milk constituents except ash significantly $(\mathrm{P}<0.05)$ increased with baker's yeast supplementation in lactating Buffaloes. While, Masek et al. (2008) observed that supplementation with live yeast cells significantly increased total milk yield but the chemical composition of milk was not influenced by the treatments with the exception of milk fat that was significantly higher in yeast culture group. 


\section{Abou-Elenin et al.}

On the other hand, Figure (1) showed the curve of milk yield divided into three stages. Animals fed ration supplemented with fibrozyme (G3) had the highest peak of lactation curve at third week of lactation period and the average value $(2.97 \mathrm{~kg}$ ) of milk yield through first five weeks of lactation period than the others. Animals fed ration supplemented with bacteria isolated (G2) had the highest average value $(2.31 \mathrm{~kg})$ during second stage (from sixth week to eleventh weeks) followed by those fed yeast culture additive $(2.23 \mathrm{~kg})$, then fibrozyme additive $(2.20 \mathrm{~kg})$ and the lowest one was observed with those fed control ration without additive $(1.79 \mathrm{~kg})$. Regarding the milk production persistency (Fig. 1), animals fed ration with bacteria isolated (G2) had a greater persistency till at the ninth week of lactation period followed by those fed ration supplemented with yeast culture and fibrozyme, respectively, in comparison with those fed control ration which, declined sharply till the end of the experimental period.

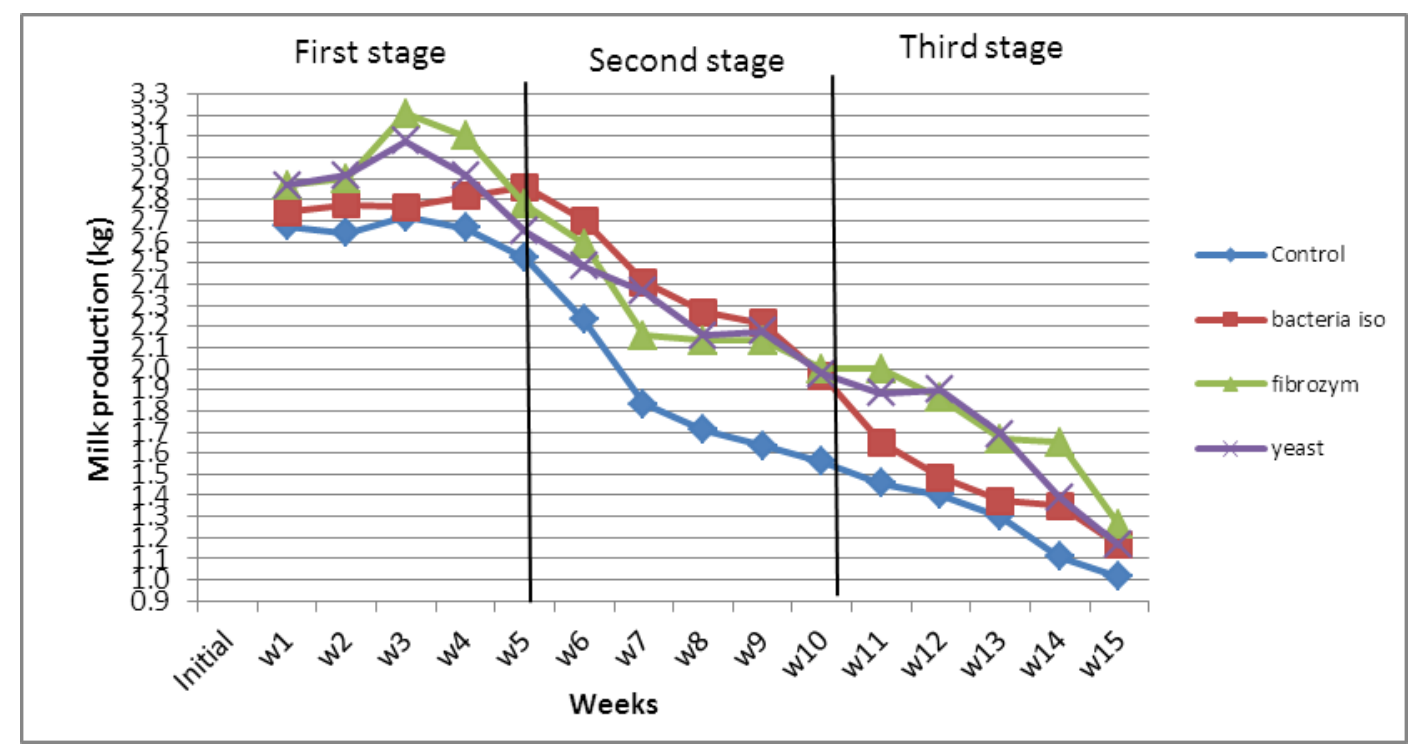

Fig. (1): Effect of experimental rations (G1, G2, G3 and G4) on three stages of milk yield period.

\section{Blood parameters:}

Results obtained in Table (5) indicated that group animals fed supplemented ration (G4) had a significantly $(\mathrm{p}<0.05)$ higher concentration of plasma protein fraction such as total protein $(\mathrm{TP})$, Albumin (AL) and globulin (G) compared with those G1, G2 and G3.

Table (5): Some blood parameters of lactating Zaraibi Goats fed experimental rations.

\begin{tabular}{|c|c|c|c|c|c|}
\hline \multirow[b]{2}{*}{ Item } & \multicolumn{4}{|c|}{ Experimental rations } & \multirow{2}{*}{$\pm \mathrm{SE}$} \\
\hline & G1 & G2 & G3 & G4 & \\
\hline T. protein $(\mathrm{g} / \mathrm{dl})$ & $4.91^{\mathrm{b}}$ & $5.43^{\mathrm{b}}$ & $5.54^{\mathrm{b}}$ & $7.12^{\mathrm{a}}$ & 0.24 \\
\hline Albumin $(\mathrm{g} / \mathrm{dl})$ & $2.19^{\mathrm{b}}$ & $2.48^{\mathrm{b}}$ & $2.80^{\mathrm{ab}}$ & $3.09^{\mathrm{a}}$ & 0.15 \\
\hline Globulin $(\mathrm{g} / \mathrm{dl})$ & $2.71^{\mathrm{b}}$ & $2.95^{\mathrm{b}}$ & $2.74^{\mathrm{b}}$ & $4.02^{\mathrm{a}}$ & 0.27 \\
\hline Albumin: Globulin ratio & 0.81 & 0.84 & 1.02 & 0.77 & 0.38 \\
\hline Creatinine & 1.01 & 1.08 & 0.87 & 1.02 & 0.06 \\
\hline AST (IU/L) & $0.56^{\mathrm{c}}$ & $0.58^{b}$ & $0.57^{\mathrm{c}}$ & $0.60^{\mathrm{a}}$ & 0.003 \\
\hline ALT (IU/L) & $0.76^{\mathrm{b}}$ & $0.78^{\mathrm{ab}}$ & $0.81^{\mathrm{a}}$ & $0.78^{\mathrm{ab}}$ & 0.012 \\
\hline
\end{tabular}

$a, b$ and $c:$ Means in the same rows with differ rent superscripts are significantly different at $(P<0.05)$.

Differences in plasma protein fraction concentration in G2, G3 and G4 than control ration might be attributed to synthesis liver function and higher digestibility of $\mathrm{CP}$ and $\mathrm{OM}$ of tested rations, which indicated better utilization of dietary protein owing to supplemented rations with feed additives. These results were agreement with those reported by Abdel-Khalek, et al (2000) who found that serum albumin concentration was significantly higher with rate of $6.5 \%$ in calves fed supplemented ration with yeast. 
However, total protein in this study was lie within the normal range. Bush (1991) reported a positive correlation between plasma TP, AL and the absorbed or synthesized protein. Also, Ashour et al. (2004) reported that AL level is a reflection of liver function, the increase of AL indicate higher ability of the animal to synthesize and store more protein. On the other hand, all values of plasma creatinine concentrations were no significant $(\mathrm{P}>0.05)$ with supplemented rations (G1, G2, G3 and G4). Data of AST and ALT (transaminase activity) tended to be significantly $(\mathrm{P}<0.05)$ different between the groups, G4 had higher significantly $(\mathrm{P}<0.05)$ value of AST (IU/L) than G2 follow by G3 and G1. While, ALT value (IU/L) for G3 was higher significantly $(\mathrm{P}<0.05)$ than control ration. In general, from these results, it could be noticed that the supplemented rations with either enzymes or yeast culture as feed additives tended to significantly $(\mathrm{P}<0.05)$ affected in some blood parameters

\section{Feed efficiency and economic evaluation:}

Data in Table (6) noticed that feed efficiency as $\mathrm{kg} 4 \%$ FCM per one $\mathrm{kg}$ DM was higher with those fed supplemented ration with fibrozyme and bacteria isolated and yeast culture ration than those fed control ration. The highest value was recorded with fibrozyme ration (G3) followed by bacteria isolated and then yeast culture rations. Also, feed efficiency as $\mathrm{kg} 4 \%$ FCM per one $\mathrm{kg}$ TDN and $\mathrm{kg}$ DCP were the highest records with $\mathrm{G} 3$ than those in other groups

The improvement in feed efficiency observed in the current study might be attributable to greater NDF digestibility in the rumen. The similar trend was concluded by Holtshausen et al. (2011). Also, improvements in feed efficiency were due to lower DMI rather than a change in milk yield. Improving feed efficiency indicates better utilization of nutrients when TMR was treated with enzymes, with the magnitude of improvement being a linear function of enzymes dosage Dyaa El-Din et al., (2013).

Regarding the economic evaluation data (Table 6) indicated that feed cost to produced one $\mathrm{kg} 4 \%$ FCM was decrease with those fed isolated bacteria ration (G2) follow by yeast culture ration (G4) by 2.03 and $2.18 \%$, respectively, compared with the fibrozyme ration $(\mathrm{G} 3 ; 2.29 \%)$ and control ration $(\mathrm{G} 1 ; 2.26 \%)$. The same trend was recorded for net revenue (LE/doe/day) which was the highest with bacteria isolated (G2) ration followed by yeast culture (G4) and then fibrozyme (G3) rations in comparison with control ration. The increasing rates of net revenue were $123 \%, 123 \%$ and $118 \%$ for G2, G4 and then G3, respectively, comparing with control ration (100\%). While, economic efficiency was the higher value with isolated bacteria $(\mathrm{G} 2)$ followed by yeast culture (G4) than control-(G1) and fibrozyme (G3) rations.

Table (6): Feed efficiency and economical evaluation of lactating Zaraibi Goats fed experimental rations.

\begin{tabular}{|c|c|c|c|c|}
\hline \multirow[b]{2}{*}{ Item } & \multicolumn{4}{|c|}{ Experimental rations } \\
\hline & G1 & G2 & G3 & $\mathrm{G} 4$ \\
\hline \multicolumn{5}{|l|}{ Feed efficiency : } \\
\hline $\mathrm{kg} \mathrm{4 \% FCM} / \mathrm{kg}$ DM feed intake & 1.19 & 1.36 & 1.39 & 1.34 \\
\hline $\mathrm{kg} 4 \% \mathrm{FCM} / \mathrm{kg}$ TDN feed intake & 2.14 & 2.16 & 2.35 & 2.11 \\
\hline $\mathrm{kg} 4 \% \mathrm{FCM} / \mathrm{kg}$ DCP feed intake & 9.42 & 11.38 & 11.41 & 9.91 \\
\hline \multicolumn{5}{|l|}{ Economic evaluation: } \\
\hline Milk price (LE /day) & 8.54 & 9.76 & 10.29 & 10.09 \\
\hline Feed cost (LE/day) & 4.13 & 4.32 & 5.06 & 4.66 \\
\hline Feed cost / kg 4\%FCM & 2.26 & 2.03 & 2.29 & 2.18 \\
\hline Net revenue(LE/doe/day) $)^{\mathrm{A}}$ & 4.42 & 5.44 & 5.23 & 5.43 \\
\hline Increasing rates of net revenue $(\%)$ & 100 & 123 & 118 & 123 \\
\hline Economic efficiency ${ }^{\mathrm{B}}$ & 2.07 & 2.26 & 2.03 & 2.17 \\
\hline Improvement & 100 & 109 & 98 & 105 \\
\hline \multicolumn{5}{|c|}{$\begin{array}{l}\text { Price of feedstuffs and supplementation: } 2400 \text { LE/Ton of concentrate feed mixture (CFM) and } 400 \text { LE/Ton } \\
\text { berseem, } 10 \text { LE/kg of bacteria isolated, } 35 \text { LE/kg of yeast culture, } 75 \text { LE/kg of fibrozyme and } 4.5 \text { LE/kg raw milk. } \\
1 \$ \text { US }=6.20 \text { LE (Egyptian pound) } \\
{ }^{A} \text { Net revenue (LE/doe.day)= money output - money input } \\
{ }^{B} \text { Efficiency = money output/money in put }\end{array}$} \\
\hline
\end{tabular}

Recent data indicate that microbial additives may a benefit ruminant nutrition (in terms of live weight gain and milk production) by a similar magnitude to ionophores ( 7 or $8 \%$ improvement; Wallace and 


\section{Abou-Elenin et al.}

Newbold, 1993), in this case by increasing feed intake rather than feed efficiency (Williams and Newbold, 1990).

These results came on line with those obtained by Abd El-Galil (2008). Scott and David (1992) showed that the Direct-Fed Microbial (DFM) is defined as alive (viable) naturally- occurring microorganisms and this includes bacteria, fungi and yeast. The DFM improves the intestinal microbial balance of host animal in favor of beneficial gut microflora (Cruywagen et al., 1996). It may also help prevent ruminal acidosis (Nocek et al., 2000) and can improve the feed efficiency and average daily weight gain of feedlot cattle (Rust et al., 2000).

\section{CONCLUSION}

Results of the current study indicated that using bacteria isolated fibrozyme and yeast culture as feed additives in lactating Goats rations increased nutrients digestibility, feeding values, milk yield prolonged the persistency period and maintained body weight change. From the economical point, it is clear those bacteria isolated supplementation is the cheapest and extremely equal feed efficiency with adding yeast culture. So, both of them are economically profitable in dairy Goats rations than adding fibrozyme or no additive.

\section{REFERENCES}

A.O.A.C. (2000). Official Methods of Analysis. $17^{\text {th }}$ ed. Association of Official Analytical Chemists International. Arlington, VA.

Abd El-Galil, Etab, R.I. (2008). Effect of bacterial treatments on chemical composition, cell wall constituents and digestibility of rice straw. Egyptian Journal of Nutrition and Feeds, 11(3): 497-510.

Abd El-Galil, Etab, R.I. (2014). Using biological additives to manipulate rumen fermentation and improve baladi goats performance. Egyptian Journal of Nutrition and Feeds, 17 (1): 29-42.

Abdel-Khalek, A.E; A.F. Mehrz and E.A. Omar (2000). Effect of yeast culture (Lacto-Sacc) in rumen activity, blood constituents and grow of suckling Friesian calves. Proceeding of the Conference on animal production in the 21 ${ }^{\text {st }}$ century, Sakha, Kafr- EL Sheikh, 18-20 April 2000.

Abou-Elenin, Ebtehag, I. M.; Hoda, M. El-Hosseiny and H.M. El-Shabrawy (2011). Comparing effects of organic acid (malate) and yeast culture as feed supplement on dairy cows performance. Nature and Science, 2011; 9(7) http://www.sciencepub.net/nature

Adams, A.L; B. Harries; Jr., H.H. Van Horn and C.J. Wilcox (1995). Effect of varying forage types on cotton seed, tallow and yeast. J. of Dairy Sci., 78: 573

Allam, A.M.; K. El-Shazly; B.E.A. Borhami and M.A. Mohamed (2001). Effect of baker's yeast (Saccharomyces Cerevisiae) supplementation on digestion in sheep and milk response in dairy cows. Egyptian Journal of Nutrition and Feeds, 4:315.

Ashour, G.; S.A. Ibrahim; A.M. Ismaeal and K.H.EL Kholy (2004). Physiological reactions and biological performance of rabbits to summer heat stress. $2^{\text {th }}$ Sci., Conference. on physiological. Response. to Environmental. Condition, 28-31 July- Arish. Egypt, P.165.

Beauchemin, K.A.; D. Colombatto; D.P. Morgavi and W.Z. Yang (2003). Use of exogenous fibrolytic enzymes to improve feed utilization by ruminants. J. of Anim. Sci., 81(E. Suppl. 2): E37-E47

Bowman, G. R.; K. A. Beauchemin and J.A. Shelford (2002). The proportion of the diet to which fibrolytic enzymes are added affects nutrient digestion by lactating dairy cows. . J. of Dairy Sci., 85: 3420-3429.

British Standard Institution (1951). Gerber method for the determination of fat in milk and milk products. Publication No.696 Part 2. 
Bush, B.M. (1991). Interpretation of laboratory results for small animal clinicians. Oxford black well scientific publications, London.

Chademana, I. and N.W. Offer (1990). The effect of dietary inclusion of yeast culture on digestion in the sheep. Animal Production, 50: 483-489.

Cruywagen,C.V.; I.Jordaan and L.Venter (1996). Effect of lactobacillus acidophillus supplementation of milk replacer on preweaning performance of calves. J. of Dairy Sci., 79:483-486

Dann, H. M.; J.K. Drackley; G.C., Mccoy; M. F. Hutjens and J. E. Garrett (2000). Effect of yeast culture (Saccharomyces Cerevisiae) on prepartum intake and postpartum intake and milk production of Jersey cows. J. of Dairy Sci., 83: 123.

Dawson, K.A. (1993). Probiotics and enzymes in ruminant nutrition. In: C. Wenk and M. Boessinger (Ed.) Enzymes in Animal Nutrition. Proc. 1st Symp., Kartause Ittingen, Switzerland, p 89.

Duncan, D.B., (1955). Multiple range and multiple F-test. Biometrics. 11:1

Dyaa El-Din A.M; B.E. Borhami; K.A. El-Shazly and S.M.A. Sallam (2013). Effect of dietary supplementation with fibrolytic enzymes on the productive performance of early lactating dairy cows. Journal of Agricultural Science, 5(6):146-155.

El El-Ashry, M.A.; Afaf, M. Fayed; K.M. Youssef; F.A. Salem and Hend, S. Aziz (2003). Effect of feeding flafomycin or yeast as feed supplement on lamb performance in Sinai. Egyptian Journal of Nutrition and Feeds, 4:1009.

El-Ashry, M.A.; Zeba, A. Motagally and Y.A. Maareck (2001). Effect of live dried baker's yeast and yeast culture on performance of growing buffalo calves. Egyptian Journal of Nutrition and Feeds, 4:607.

Gaafar, H.M.A.; A.M.A. Mohi El-Din; M.I. Bassiouni and K.F.A. El-Riedy (2009). Effect of concentrate to roughage ratio and baker's yeast supplementation during hot season on performance of lactating buffaloes. Slovakia Journal of Animal Science, 42:188.

Gaines, W.L. (1923). Relation between percentage of fat content and yield of milk.1- Correction of milk yield for fat content. Agric. Exo. Sta. Bull., 245.

Gomez- Alcron, R.; C. Dudas and J.T. Huber (1987). Effect of Aspergillus oryzae (Amaferm) and yeast on feed utilization by Holstein cows. J. of Dairy Sci., 70:218. (Abstr.).

Hadjipanayiotou, M.; I.Antoniou and A. Photiou (1997). Effects of the inclusion of yeast culture on the performance of dairy ewes and goats and the degradation of feedstuffs. Livestock Production Science, 48: $129-134$.

Harrison, G.A.; R.W. Hemken; K.A. Dawson; R.J. Harmon and K.B. Barker (1988). Influence of addition of yeast culture supplement to diets of lactating cows on ruminal fermentation and microbial populations. J. of Dairy Sci., 71:2967.

Hillman, K.; D. Lloyd and A.G. Williams (1985). Use of a portable quadrupole mass spectrometer for the measurement of dissolved gas concentrations in ovine rumen liquor in situ. Curr. Microbiol. 12: 335.

Holtshausen, L.; Y.H. Chung; H. Gerardo-Cuervo; M. Oba and K. A. Beauchemin (2011). Improved milk production efficiency in early lactation dairy cattle with dietary addition of a developmental fibrolytic enzyme additive. . J. of Dairy Sci., 94: 899-907.

Hristov, A. N., T. A. McAllister and K. J. Cheng (1998). Effect of dietary or abomasal supplementation of exogenous polysaccharide-degrading enzymes on rumen fermentation and nutrient digestibility. J. of Anim. Sci., 76:3146-3156.

Hutjens, M.F (1991). Feed additives. Vet. Clinics North Am.: Food Animal Practice.7: 2-525.

Khattab, H.M.; F.A. Salem; Mohamed M. Sayeda and H.M. Nagh (2003). Effect of Yea-sacc, lacto-Sacc supplementation and energy levels on performance, rumen activity, some blood constituents and carcass traits in growing sheep. Egyptian Journal of Nutrition and Feeds, 4: 981. 


\section{Abou-Elenin et al.}

Krause, M.; K.A. Beauchemin; L.M. Rode; B.I. Farr and P. Nørgaard (1998). Fibrolytic enzyme treatment of barley grain and source of forage in high-grain diets fed to growing cattle. J. of Anim. Sci., 96:1010-1015.

Lewis, G.E.; W.K. Sanchez; C.W. Hunt; M.A. Guy; G.T. Prichard; B.I. Swanson and R. Treacher (1999). Effect of direct-fed fibrolytic enzymes on the lactational performance of dairy cows. J. of Dairy Sci., 82:611-617.

Ling, E.R. (1963). Text Book of Dairy Chemistry Vol. 11 Practical Chapman Hall, LTD, London, $4^{\text {th }}$ ed. Pp. 140.

Majennier (1949). Method of analysis of milk and its products. Milk industry foundation. Washington, D.C.

Maklad, E.H.M. and B.K. Mohamed (2001). Comparison among the effects of clover hay and corn silages as feed ingredients on the nutritive value, bacterial strains and fermentation in the rumen of sheep. Journal of Agricultural Science Mansoura University., 25(12): 7592-7597.

Masek,T., Z. Milkulec, H. Valpotic, L.Kusce, N. Mikulec, N.Antunac (2008). The influence of live yeast cells (Saccharomyces Cerevisiae) on the performance of grazing dairy sheep in late lactation. Vetrinary Arhives., 78:95.

McAllister, T.A.; A.N. Hristov; K.A. Beauchemin; L.M. Rode and K.J. Cheng (2001). Enzymes in ruminants diets (Ed. M.R. Bedford and G.G. Partridge). Enzymes in Farm Animal Nutrition CAB International, pp. 273-298.

Mekasha, Y; A. Tegegne; A. Yami and N. N. Umunna (2002). Evaluation of non- conventional agroindustrial by-products as supplementary feeds for ruminants: In vitro and metabolism study with sheep. Small Ruminant Research, 44:25-35.

Newbold, C.J.; S. Lopez; N. Nelson; J.O. Ouda; R.J. Wallace and A.R. Moss (2005). Propionate precursors and other metabolic intermediates as possible alternative electron acceptors to methanogenesis in ruminal fermentation in vitro. British. Journal. of Nutrition, 94:27.

Newbold, C.J.; P.E.V. Williams; N. Mckain; A. Walker and R.J. Wallace (1990). The effect of yeast culture on yeast numbers and fermentation in the rumen of sheep. Proc. Nutr. Soc., 49:474.

Newbold, C.J.; R.J. Wallace and F.M. McIntosh (1993). The stimulation of rumen bacteria by Saccharomyces cerevisiae is dependent on the respiratory activity of the yeast. J. of Anim. Sci., 71(Suppl. 1):280 (Abstr.).

Newbold, C.J.; R.J. Wallace and N.D. Watt (1992). Properties of ionophore-resistant Bacteroides ruminicola enriched by cultivation in the presence of tetronasin. Journal Applied. Bacteriology, 72:65.

Newbold, C.J.; R.J. Wallace and F.M. McIntosh (1996). Mode of Action of the Yeast Saccharomyces cerevisiae as feed additive for ruminants. British. Journal. of Nutrition, $76: 249-261$.

Nocek, J.E.; W.P., Kautz; J.A.Z. Leedle and J.G. Allman (2000). Altering diurnal pH and in situ digestion in dairy cows with ruminal supplementation of direct-fed microbials (DFM) and yeast. J. of Dairy Sci., 83(suppl.1):1242.

NRC (1988). Nutrient Requirements of Dairy Cattle.6th Rev. Ed., National Research Council Acad. Sci., Washington, DC, USA.

Offer, N.W. (1990). Maximising fiber digestion in the rumen: The role of yeast culture. In: T.P. Lyons (Ed.) Biotechnology in the Feed Industry. p 79. Alltech Technical Publications, Nicholasville, KY.

Putnam, D.E.; C.G. Schwab; M.T. Socha; N.L. Whitehouse; N.A. Kierstead and B.D. Garthwaite (1997). Effect of yeast culture in the diets of early lactation dairy cows on ruminal fermentation and passage of nitrogen fractions and amino acids to the small intestine. J. of Dairy Sci., 80: 374-384.

Rahma, E.; O. Kärt; K. Mhhejev; M. Henno; I. Jõudu and T. Kaart (2009). Effect of dietary live yeast on milk yield, composition and coagulation properties in early lactation of Estonian Holstein cows. Agraarteadus: Journal of Agricultural Science, Akadeemilise Põllumajanduse Seltst väljaanne.XVIIIm 37. 
Rust, S.R.; K. Metz and D.R. Ware (2000). Effect of bovamine rumen culture on the performance and carcass characteristics of feedlot steers. Mich. Agric. Ex. Sto. Beef, Cattle, Sheep and Forage Sys. Res. Dem. Rep. No.569, East Lansing, pp: 22-26.

Salem, F.A.F.; Hanaa, H. El-Amary and S.H. Hassanin (2001). Effect of bentonite supplementation on nutrients digestibility, rumen fermentation, some blood physiological parameters and performance of growing lambs. Egyptian Journal of Nutrition and Feeds, 4: 179-191.

SAS (1999). SAS Procedure Guide. Version 6.12 Edition. SAS Institute Inc.,Cary,NC, USA.

Scott, A.M. and J.N. David (1992). Effect of direct fed microbial on rumen fermentation. J. of Dairy Sci., 75:1736-1744.

Van Keulen, J. and P.A. Young (1977). Evaluation of acid insoluble ash as a natural marker in ruminant digestibility studies. J. of Anim. Sci., 44: 282.

Van Soest P.J., J.B. Robertson, B.A. Lewis (1991). Methods for dietary fiber, neutral detergent fiber, and nonstarch polysaccharides in relation to animal nutrition. J. of Dairy Sci., 74, 3583-3597.

Wallace, R.J. and C.J. Newbold (1993). Rumen fermentation and its manipulation: the development of yeast cultures as feed additives. In: T.P. Lyons (Ed.) Biotechnology in the Feed Industry.. Alltech Technical Publications, Nicholasville, KY. p 173

Wallace, R.J. and C.J. Newbold (1992). Probiotics for Ruminants. In: Probiotics: The Scientific Basis. R. Fuller, (Ed.). London: Chapman and Hall.

Ware, R.A. and R.A. Zinn, (2005). Influence of Maceration and fibrolytic enzyme on the feeding value of rice straw. Journal of Animal Veterinary Advanced, 4:387-392.

Williams, P.E.V. and C.J. Newbold (1990). Rumen probiosis: the effects of novel microorganisms on rumen fermentation and ruminant productivity. In: W. Haresign and D.J.A. Cole (Ed.) Recent Advances in Animal Nutrition .1990. Butterworths, London. p 211

Williams, P.E.V. (1989). The mode of action of yeast culture in ruminant diets: A review of the effect of rumen fermentation patterns. In: T. P. Lyons (Ed.) Biotechnology in the Feed Industry.

Williams, P.E.V., C.A.G.Tait, G.M.L.I.nnes and C.J. Newbold (1991). Effect of the inclusion of yeast culture (Saccharomyces Cerevisiae) plus growth medium in the diet of dairy cows on milk yield and forage degradation and fermentation patterns in the rumen of steers. J. of Anim. Sci., 69:3016.

Williams, P.E.V.; A. Walk and J.C. macrae (1990). Rumen probiosis: The effect of yeast culture (viable yeast) Saccharomyces Cervisiae (growth medium) on duodenal protein flow in wether sheep. Proceeding of Nutritional. Society, $49: 128 \mathrm{a}$ (Abstract).

Yoon, I.K. and M.D. Stern (1996). Effect of Saccharomyces Cerevisiae and Aspergillus oryzae cultures on fermentation in dairy cows. J. of Dairy Sci., 79: 411. 
أثر تغذية المصادر الميكروبيولوجية الطبيعية على الأداء الانتاجى للماعز الحلاب

\author{
ابتهاج ابراهيم محمد أبو العنين، عتاب رمضان عبد الجليل، كامل عتمان ابراهيم عتمان11 حامد محمد الثبراوى1

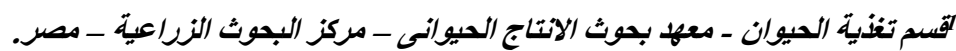

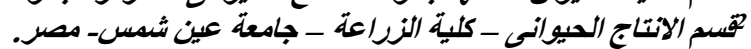

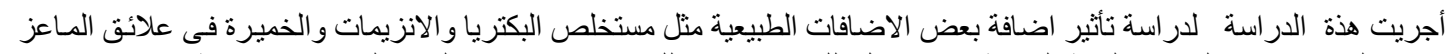

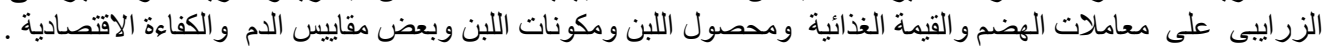

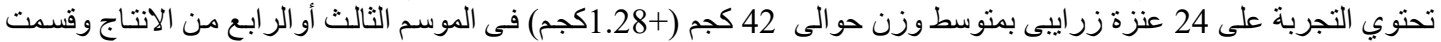

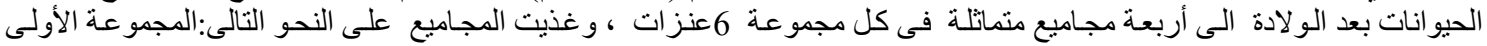

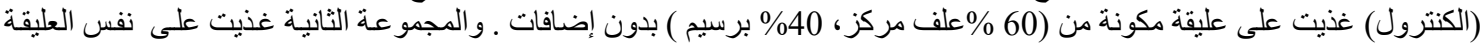

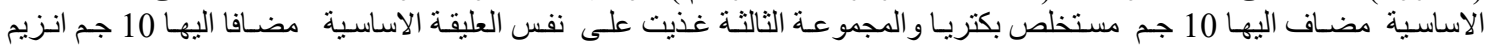
و المجمو عة الر ابعة غذيت على نفس العليقة الاساسية مضـافا اليها 10 فم خميرة (Fibrozyme)

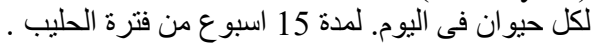

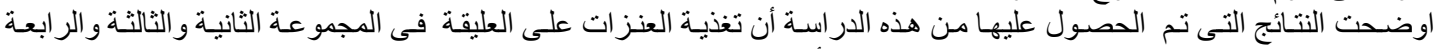

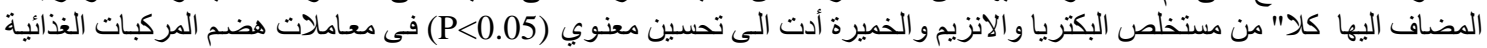

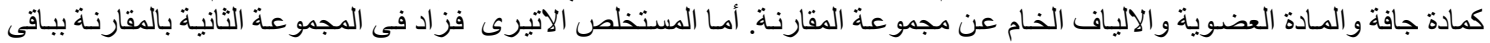

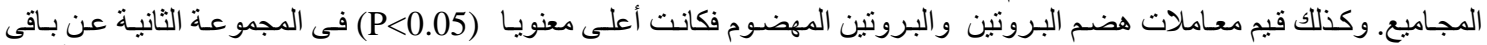

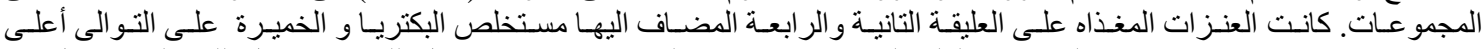

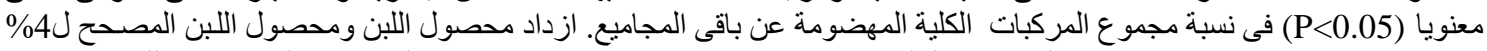

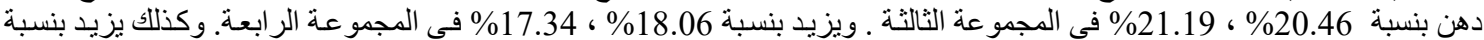

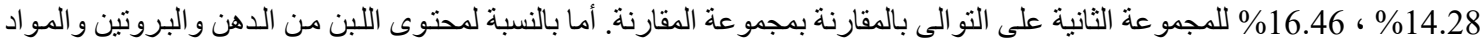

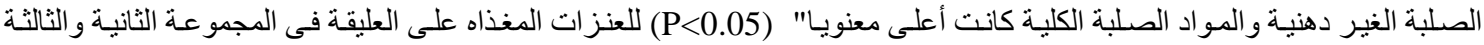

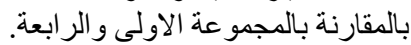

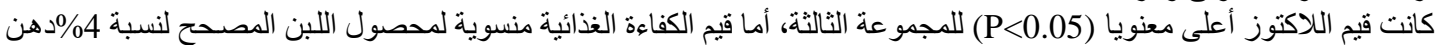

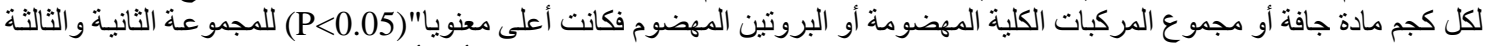

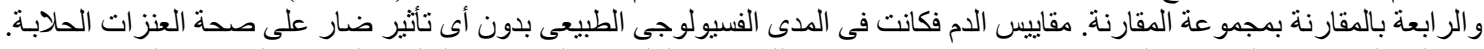

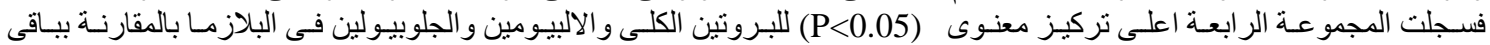

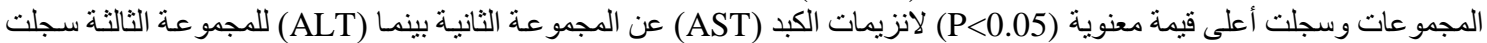

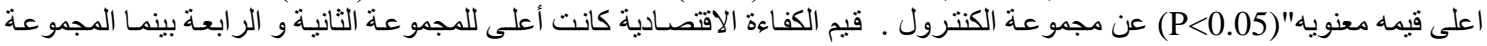

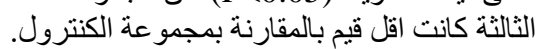

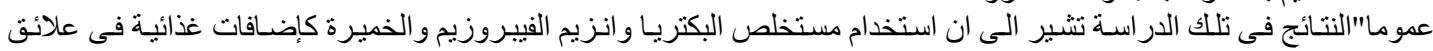

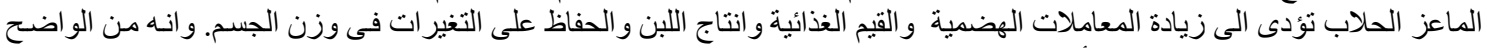
ان استخدام مستخلص البكتريا كان الأقل تكلفة اقتصاديا". 